J. Natn. Sci. Coun. Sri Lanka 1987 15(1): $61-69$

\title{
ZINC AND COPPER CONTENT OF SOME COMMON FOODS
}

\author{
T. M. S. ATUKORALA \\ Department of Biochemistry, Faculty of Medicine, University of Colombo, Colombo 3.
}

and

U. S. de S. WAIDYANATHA

Department of Chemistry, Faculty of Science, University of Colombo, Colombo 3.

(Date of receipt : 08 October 1985)

(Date of acceptance : 23 Marcb 1987)

\begin{abstract}
The zinc and copper contents of some plant and animal foods commonly available in Sri Lanka were determined. The bio-availability of zinc in plant foods was assessed by determining their phytate content. The food samples in their raw, uncooked state were subjected to wet digestion and the respective concentrations of zinc and copper were measured by atomic absorption spectroscopy. The phytate phosphorus content of plant foods was determined by the method of Oberleas. The zinc content of foods was higher than that of copper. Fish and Ox liver were the richest sources of zinc and copper. All animal foods studied could make a significant contribution to the supply of zinc in the diet. Of the plant foods analysed, pulses were good sources of both nutrients, while cereals and starchy roots contained moderate amounts. However, both pulses and cereals had phytate to zinc molar ratios exceeding 12 , thus decreasing the bio-availability of zinc in these foods. Green leafy vegetables and legumes had higher amounts of copper and bio-available-zinc compared to other vegetables and fruits.
\end{abstract}

\section{Introduction}

Zinc and copper are two of the most metabolically active and intensively investigated trace metal nutrients. The established biochemical role of zinc is as a component of many metalloenzyme systems, including some enzymes which play a central role in nucleic acid metabolism. In addition, zinc is now known to be a membrane stabiliser and a stimulator of the immune response. ${ }^{5}$ Deficiency of zinc leads to many clinical manifestations including impaired growth and sexual maturation. ${ }^{10}$ Copper is also a component of many important enzyme systems, such as cytochrome oxidase, lysyl oxidase and ceruloplasmin, an iron-oxidising enzyme in blood. ${ }^{6}$ The observation of anaemia in copper deficiency may probably be related to its role in facilitating iron absorption and in the incorporation of iron in to haemoglobin. ${ }^{3}$

Deficiency of these two elements may arise either as a result of decreased dietary intake or as a result of decreased availability from foods, especially in zinc, where the bio-availability may be decreased by the presence of a large amount of phytate. ${ }^{11}$ Therefore, it is important to identify good dietary sources of zinc and copper. 
Knowledge of the trace element content of foods is very limited. The data available at present is based on analysis carried out on Indian foods ${ }^{7}$ and a preliminary study by Atukorala et. al. ${ }^{2}$

In the present study, the zinc and copper content of some common foods has been determined and the bio-availability of zinc in foods assessed by determining phytate content.

\section{Materials and Methods}

\subsection{Materials}

Plant and animal foods (as purchased) in their raw, uncooked state were used. The food samples were purchased in Colombo and four different samples of each item of food were collected at random and analysed and the mean \pm SEM taken. The food samples were washed thoroughly with glass distilled water and dried well with filter paper. The specimens for replicate estimations were taken from different parts of each food. Each food sample was analysed in quadruplicate, for the estimation of zinc and copper and in duplicate for the determination of phytate.

The variation of zinc and copper content of plants with environmental conditions, specially, soil conditions; "was evaluated by determining the content of these elements in 2 varieties of green leafy vegetables (Centella asiatica - "Gotukola" and Alternanthera sessilis - "Mukunuwenna") collected from 5 different areas of Sri Lanka. There was no statistically significant difference in the values obtained from the 5 areas.

All glassware used was soaked overnight in dilute hydrochloric acid, washed thoroughly with glass distilled water and dried prior to use. Analytical grade reagents $(\mathrm{BDH})$ were used in all experiments.

\subsection{Methods}

\subsubsection{Estimation of zinc and copper}

The organic matrix of foods was destroyed by wet digestion. ${ }^{9}$ A weighed amount $(0.2-0.5 \mathrm{~g})$ of food was digested by heating with a mixture of conc. nitric acid and $65 \%$ perchloric acid. The residue obtained was dissolved in $2 \mathrm{M}$ hydrochloric acid and the concentration of zinc and copper was determined by atomic absorption spectrometry.

Zinc acetate dihydrate and copper sulphate pentahydrate were used to prepare standard solutions. The absorbance of working standard solutions was checked with standard solutions for atomic absorption spectroscopy (Sigma). The standards and blanks were processed in the same manner as the 
samples. The mean percentage recoveries for zinc and copper were found to be $98.20 \pm 0.67$ and $97.51 \pm 0.87$ respectively. The absorption was measured using a Varian AA 75 Atomic absorption spectrophotometer. The following conditions were used in measurement.

Lamp current (mA)

Wave length ( $\mathrm{nm}$ )

Spectral band pass (nm)

\section{Copper}

4

324.7

0.5
Zinc

\section{5}

213.9

1.0

\subsubsection{Estimation of phytate}

The phytate content was determined by a direct phosphate method. ${ }^{8}$ Hydrochloric acid (1.2\%) containing $10 \%$ sodium sulphate was used for the extraction of phytic acid. Phytate phosphorus was hydrolysed by digesting with a mixture of concentrated sulphuric acid and perchloric acid $(3: 1)$. The digest was diluted and the phosphate content determined by the method of Gomeri. 4

2.2.3 The moisture content of foods was determined using an Infra Red moisture meter.

\section{Results and Discussion}

The zinc and copper contents of some foods commonly available in Sri Lanka were determined and expressed on a wet weight basis. In general, the zinc content of almost all foods tended to be higher than that observed for copper.

Of the animal foods analysed (Table 1), fish liver was the richest source of zinc, while ox liver was the richest source of copper. Beef muscle had a higher zinc content compared to chicken or different varieties of fish, while chicken muscle and prawns had higher amounts of copper compared to other types of meat or fish. Eggs contained large amounts of both zinc and copper, while milk was a good source of zinc. 
Table 1. Zinc and copper content of animal foods

\begin{tabular}{cccc}
\hline Commodity & $\begin{array}{c}\text { zinc } \\
(\mathrm{mg} / 100 \mathrm{~g}\end{array}$ & $\begin{array}{c}\text { Coper } \\
(\mathrm{mg} / 100 \mathrm{~g} \\
\text { wet weight })\end{array}$ & $\begin{array}{c}\text { Moisture } \\
\text { wet weight })\end{array}$ \\
\hline
\end{tabular}

Liver

$\begin{array}{llll}\text { Ox Liver } & 3.786 \pm 0.289 & 2.515 \pm 0.203 & 76.0 \\ \text { Fish liver ("Para") } & 6.134 \pm 0.673 & 1.969 \pm 0.164 & \text { N.D. }\end{array}$

Meat

$\begin{array}{llll}\text { Beef, muscle } & 2.340 \pm 0.338 & 0.211 \pm 0.025 & 78.0 \\ \text { Chicken, muscle } & 1.370 \pm 0.176 & 0.436 \pm 0.060 & \text { N.D. }\end{array}$

Fish

$\begin{array}{llll}\text { Seer (Scomber sp.)* } & 1.470 \pm 0.169 & 0.148 \pm 0.033 & 73.0 \\ \text { "Para" (Carangids sp.)* } & 1.678 \pm 0.155 & 0.085 \pm 0.014 & \text { N.D. } \\ \text { "Kelawalla" (Eutbynnus sp.)* } & 1.128 \pm 0.100 & 0.133 \pm 0.013 & 71.0 \\ \text { "Hurulla" (Sardinella sirus) } & 0.930 \pm 0.087 & 0.155 \pm 0.048 & 76.4 \\ \text { "Salaya" (Sardinella Jussieu) } & 1.023 \pm 0.198 & 0.137 \pm 0.019 & 78.3 \\ \text { Prawns (Penaeus sp.)* } & 1.349 \pm 0.270 & 0.414 \pm 0.108 & 77.4\end{array}$

Eggs

Hen (whole) $\quad 1.185 \pm 0.119 \quad 0.295 \pm 0.037 \quad 73.5$

Milk

(Pasteurised, bottled) $\quad 0.900 \pm 0.017 \quad$ trace 100

Each value is the mean \pm SEM of 4 samples.

* The edible portion without skin or shell was used for analysis.

N.D. - not determined.

All animal foods studied could make a significant contribution to the supply of zinc in the diet. Moreover; the zinc in animal foods is more bio-available than in plant foods owing to absence of phytate in animal foods. Most animal foods were moderate sources of copper, except for milk, which contained only traces of this nutrient. 
Table 2. Zinc and copper content of cerepals, pulses and starchy roots

\begin{tabular}{lccc}
\hline Commodity & $\begin{array}{c}\text { Zinc } \\
\text { (mg/100g } \\
\text { wet weight) }\end{array}$ & $\begin{array}{c}\text { Copper } \\
\text { (mg/100g } \\
\text { wet weight) }\end{array}$ & $\begin{array}{c}\text { Moisture } \\
\text { (g/100g) }\end{array}$ \\
\hline Rice & & & \\
$\quad$ Raw, milled ("kekulu") & $0.980 \pm 0.109$ & $0.260 \pm 0.023$ & 15.0 \\
Parboiled, milled ("Samba") & $1.110 \pm 0.030$ & $0.220+0.090$ & 15.0 \\
Parboiled, lightly milled ("Samba") & $1.460 \pm 0.110$ & $0.327 \pm 0.033$ & 15.0 \\
Flour & & & \\
Wheat (white, 70\% extraction) & $1.193 \pm 0.189$ & $0.240 \pm 0.041$ & 15.0 \\
Rice & $1.870 \pm 0.030$ & $0.490 \pm 0.060$ & 15.0 \\
Soya (Glycine max) & $3.940 \pm 0.160$ & $2.473 \pm 0.180$ &. \\
& & & \\
Pulses & & & \\
Cowpea (Vigna unguiculata) & $2.835 \pm 0.060$ & $0.609 \pm 0.043$ & - \\
Mysoor-dhal (Cajanus cajan) & $2.683 \pm 0.110$ & $1.070 \pm 0.010$ & 19.0 \\
"Mung" (Phaseolus aureus) & $2.620 \pm 0.020$ & $1.071 \pm 0.100$ & 16.5 \\
Mung-dhal (Pbaseolus aureus) & $2.350 \pm 0.080$ & $1.035 \pm 0.030$ & \\
Starchy roots* & & & \\
Potat، (Solanum tuberosum) & $1.133 \pm 0.230$ & $0.328 \pm 0.061$ & 80.0 \\
Sweet Potato (Ipomea batatas) & $0.595 \pm 0.170$ & $0.172 \pm 0.023$ & 70.0 \\
"Manioc (Manibot esculenta) & $1.103 \pm 0.091$ & $0.590 \pm 0.081$ & - \\
"Kiriala" (Colacasia esculenta) & $0.860 \pm 0.013$ & $0.631 \pm 0.030$ & - \\
\hline
\end{tabular}

Each value is the mean $\pm S E M$ of 4 samples.

- Edible portion without skin was used for analysis.

All varieties of rice were moderate sources of zinc and copper, with a noticeable decrease due to milling and polishing. (Table 2). Parboiling seemed to reduce the loss of nutrients during milling and polishing. A decrease in zinc content of rice with increase in degree of polishing has also been reported in studies carried out in India. ${ }^{7}$ Rice flour had a higher content of zinc and copper compared to $70 \%$ extraction wheat flour. Pulses were good sources of both zinc and copper (Table 2) and soya flour had higher amounts of both nutrients. In pulses too, the tracc element content decreased with increase in milling and polishing. This is evident from studies on Mung and Mung dhal. Starchy roots had moderate amounts of both zinc and copper (Table 2). 
Table 3. Zinc and copper content of vegetables

\begin{tabular}{|c|c|c|c|}
\hline Commodity & $\begin{array}{c}\text { Zinc } \\
(\mathrm{mg} / 100 \mathrm{~g} \\
\text { wet weight })\end{array}$ & $\begin{array}{c}\text { Copper } \\
\text { mg/100g } \\
\text { wet weight) }\end{array}$ & $\begin{array}{l}\text { Moisture } \\
\text { (g/100g) }\end{array}$ \\
\hline \multicolumn{4}{|l|}{ Dark green leafy vegetables: } \\
\hline "Gotukola" (Centella asiatica) & $3.930 \pm 0.810$ & $0.555 \pm 0.041$ & 95.0 \\
\hline \multicolumn{4}{|l|}{ "Mukunuwenna" (Alternantbera } \\
\hline sessilis) & $2.545 \pm 0.625$ & $0.363 \pm 0.024$ & 85.0 \\
\hline \multicolumn{4}{|l|}{ "Kathurumurunga" (Sesbania } \\
\hline grandiflora) & $2.473 \pm 0.483$ & $0.145 \pm 0.015$ & N.D. \\
\hline "Kankun" (Ipomea aquatica) & $1.270 \pm 0.108$ & $0.221 \pm 0.023$ & 90.0 \\
\hline Spinach (Basella alba) & $0.783 \pm 0.230$ & $0.440 \pm 0.120$ & 95.0 \\
\hline "Sarana" (Triantbema decandra) & $1.077 \pm 0.188$ & $0.416 \pm 0.057$ & N.D. \\
\hline \multicolumn{4}{|l|}{ Other vegetables } \\
\hline Brinjals (Solanum melongena) & $1.300 \pm 0.529$ & $0.236 \pm 0.104$ & N.D. \\
\hline Carrots (Daucus carota) & $0.901 \pm 0.190$ & $0.243 \pm 0.026$ & 89.5 \\
\hline "Kekiri" (Cucumis melo var. agrestis) & $0.434 \pm 0.052$ & $0.105 \pm 0.063$ & 98.0 \\
\hline Ladies fingers (Hibiscus esculentus) & $1.406 \pm 0.392$ & $0.129 \pm 0.001$ & N.D. \\
\hline Bitter-gourd (Momordica charantia) & $0.743 \pm 0.0 .10$ & $0.105 \pm 0.007$ & 91.0 \\
\hline Jak (Artocarpus beteropbyllus) & $0.660 \pm 0.080$ & $0.300 \pm 0.044$ & N.D. \\
\hline Ash plantain (Musa sapientum var.) & $0.931 \pm 0.280$ & $0.130 \pm 0.021$ & N.D. \\
\hline Cabbage (Brassica oleracea) & $0.603 \pm 0.030$ & $0.043 \pm 0.010$ & 95.0 \\
\hline \multicolumn{4}{|l|}{ Legumes } \\
\hline Green bean (Pbaseolus vulgaris) & $2.150 \pm 0.072$ & $0.226 \pm 0.046$ & 90.6 \\
\hline String bean (Vigna cylindrica) & $1.646 \pm 0.304$ & $0.232 \pm 0.026$ & 90.0 \\
\hline \multicolumn{4}{|l|}{ Winged bean (Psopbocarpus } \\
\hline tetragonolobus) & $1.346 \pm 0.254$ & $0.230 \pm 0.038$ & N.D. \\
\hline
\end{tabular}

Each value is the mean \pm SEM of 4 samples.

N.D. - not determined

Dark green leafy vegetables were good sources of both zinc and copper with "Gotukola" (Centella asiatica) having the highest amount of both nutrients (Table 3). There was considerable variation in zinc and copper content among the other vegetables studied. Legumes had a higher content of zinc composed to the other vegetables. The lowest copper content was seen in cabbage.

These results are similar to the values reported on Indian foods. ${ }^{\text {? }}$ 
Table 4. Zinc and copper content of fruits and nuts

\begin{tabular}{|c|c|c|c|}
\hline Commodity & $\begin{array}{c}\text { Zinc } \\
(\mathrm{mg} / 100 \mathrm{~g} \\
\text { wet weight })\end{array}$ & $\begin{array}{c}\text { Copper } \\
\text { (mg/100g } \\
\text { wet weight) }\end{array}$ & $\begin{array}{l}\text { Moisture } \\
\text { (g/100g) }\end{array}$ \\
\hline \multicolumn{4}{|l|}{ Fruits } \\
\hline $\begin{array}{r}\text { Plantains (Musa sapientum) } \\
\text { "Ambul" variety }\end{array}$ & $0.473 \pm 0.170$ & $0.166 \pm 0.052$ & 80.0 \\
\hline $\begin{array}{r}\text { Plantains (Musa sapientum) } \\
\text { "Ambun" variety }\end{array}$ & $0.510 \pm 0.110$ & $0.190 \pm 0.021$ & 80.0 \\
\hline $\begin{array}{l}\text { Plantains (Musa sapientum) } \\
\text { "Kolikuttu" variety }\end{array}$ & $0.183 \pm 0.003$ & $0.320 \pm 0.040$ & 77.1 \\
\hline Pineapple (Ananas comosus) ... & $0.587 \pm 0.089$ & $0.299 \pm 0.041$ & 87.3 \\
\hline $\begin{array}{l}\text { Mango (Mangifera indica) } \\
\text { "Karthakolumban", variety }\end{array}$ & $0.618 \pm 0.065$ & $0.274 \pm 0.030$ & N.D. \\
\hline Papaw (Carica papaya) & $0.749 \pm 0.075$ & $0.292 \pm 0.040$ & 87.0 \\
\hline Avocado (Persea grattissima) & $1.015 \pm 0.200$ & $0.351 \pm 0.091$ & N.D. \\
\hline "Veralu" (Eleocarpus obovatus) & $0.783 \pm 0.130$ & $0.315 \pm 0.144$ & N.D. \\
\hline $\begin{array}{c}\text { Orange (Citrus auranteum) } \\
\text { (Sweet variety) }\end{array}$ & $0.754 \pm 0.213$ & $0.170 \pm 0.084$ & 77.2 \\
\hline Ripe Jak (Artocarpus beteropbyllus) & $0.610 \pm 0.160$ & $0.251 \pm 0.013$ & N.D. \\
\hline Coconut (Cocos nucifera) & $1.666 \pm 0.405$ & $0.946 \pm 0.083$ & N.D. \\
\hline
\end{tabular}

Each value is the mean $\mathrm{ISEM}$ of 4 samples.

N.D. - not determined.

Fruits studied contained relatively small amounts of both zinc and copper (Table 4), except for Avocado which had a moderately high zinc content. Coconut had a moderately high content of both zinc and copper.

It has been shown that the bio-availability of zinc in plant foods may be decreased by the presence of a large amount of phytate. 
Table 5. Phytate $\mathrm{P}$ content and the molar ratio of phytate to zinc in some plant foods

\begin{tabular}{|c|c|c|}
\hline Commodity & $\begin{array}{l}\text { Phytate } P^{a} \\
(m g / 100 g)\end{array}$ & $\begin{array}{l}\text { Phytate/zinc } \\
\text { molar ratio }\end{array}$ \\
\hline Cereals & & \\
\hline Rice, raw milled & 43.65 & 15.60 \\
\hline Rice, par boiled & 38.12 & 9.32 \\
\hline \multicolumn{3}{|l|}{ Flour } \\
\hline Rice flour & 88.80 & 17.05 \\
\hline Wheat flour (white, $70 \%$ extraction) & 38.44 & 11.44 \\
\hline Soya flour & 236.00 & 20.79 \\
\hline \multicolumn{3}{|l|}{ Pulses i : } \\
\hline Cowpea (Vigna unguiculata) & 144.00 & 19.37 \\
\hline "Mung" (Phaseolus aureus) & 112.80 & 15.03 \\
\hline Mysoor dhal (Cajanus cajan) & 62.44 & 15.01 \\
\hline \multicolumn{3}{|l|}{ Legumes } \\
\hline Green bean (Phaseolus vulgaris) & 37.20 & 6.06 \\
\hline Winged bean (Psopbocarpus tetragonolobus) & 11.70 & 9.30 \\
\hline String bean (Vigna cylindrica) & 5.84 & 4.96 \\
\hline \multicolumn{3}{|l|}{ Leafy vegetables } \\
\hline "Kankun" (Ypomea aquatica) & 23.40 & 6.41 \\
\hline "Kathurumurunga" (Sesbania grandiflora) & 19.40 & 2.75 \\
\hline "Gotukola" (Centella asiatica) & 19.36 & 3.09 \\
\hline “Mukunuwenna' (Alternanthera sessilis) & 4.03 & 4.01 \\
\hline \multicolumn{3}{|l|}{ Starchy roots* } \\
\hline Potato (Solanum tuberosum) & 3.72 & 1.17 \\
\hline Sweet potato (Ipomea batatas) & 2.48 & 1.12 \\
\hline Manioc (Manibot esculenta) & 6.20 & 1.97 \\
\hline
\end{tabular}

${ }^{a}$ Each value is the mean of 2 samples.

*Analyses were made on the edible portion without skin.

The phytate phosphorus content of cereals and pulses was higher than that of the vegetables (Table 5). Soya flour and cowpea had a higher content of phytin phosphorus compared to cereals and other pulses.

The possible importance of a given food as a source of zinc is determined by the molar ratio of phytate to zinc rather than by its absolute content of zinc. It has been suggested that molar ratios of phytate to zinc of 12 and above would decrease the bio-availability of zinc. ${ }^{1}$ 
Our studies show that although zinc is present in significant amour.ts in pulses and cereals, it may be less bio-available because of phytate to zinc molar ratios exceeding 12. Soya flour was the richest source of zinc among the plant foods analysed, but its bio-availability may be decreased by the high phytate to zinc molar ratio of 20.8. In contrast, green leafy vegetables and legumes which contained moderately high amount of zinc also had lower phytate to zinc molar ratios and therefore represent an important source of zinc in a Sri Lankan diet.

\section{Acknowledgements}

This work was supported by a Research Grant from the University of Colombo. We thank Dr. N. R. de Silva for his help in trace element analysis. Our thanks also go out to Professor R. S. Ramakrishna for permitting the use of the facilities at the Department of Chemistry. The technical assistance of Mr. and Mrs. M. Balasubramaniam of the Department of Chemistry is gratefully acknowledged.

\section{References}

1. ANON (1983) Nutr. Rev. 41 (2): 64-66.

2. Atukorala, T. M. S., Silva, G. K. J.\& DE Silva, N. R. (1983) Proc. Sri lanka Ass. Advmt. Sci. (abstracts) 39(1): 69.

3. FAO/WHO (1974) Hand book or buman nutritional requirements FAO Nutritional studies No. 28 p. $63-64$.

4. Gomeri, G. (1942) J. Lab. Clin. Med. $27: 955$.

5. HAMBIDGE, K. M. (1978) J. Hum. Nutr. 32:99- 100.

6. MILLS, C. F. (1981) Symposia from the XII International Congress of Nutrition Ed. A. E. Harper and G. K. Davis, Prog. Clin. Biol. Res. 77 : $165-77$.

7. National Institute of Nutrition, Annual Report (1982) Hyderabad, India p. 1 - 7.

8. OBERLEAS, D. (1971) Methods of Biochemical Analysis $20: 87-100$.

9. PEARSON, D. (1981) Chemical analysis of foods Ed. Egan, H., Kirk, R. S. and Sawyer, R., Pub. Churchill, Livingstone p. 591.

10. PRASAD, A. S. (1981) Symposia from the XII International Congress of Nutrition Ed. A. E. Harper and G. K. Davis Prog. Clin. Biol. Res. $77: 165-77$.

11. W.H.O. (1973) World Health Organisation Technical Report Series No. 532 p. $9-19$. 